\title{
How do Agency Problems Affect the Implied Cost of Capital?
}

\author{
Ching-Chih Wu, Bing-Huei Lin, and Tung-Hsiao Yang
}

\author{
Department of Finance, National Chung Hsing University, No. 250, Kuo Kuang Rd., Taichung 40227, Taiwan
}

\begin{abstract}
We test the relationship between the implied cost of capital and two agency problems, free cash flows and overinvestment. We show that free cash flows have a significant negative impact on the implied cost of capital, but overinvestment has a significantly positive impact. In addition, the pay-for-performance sensitivity has a negative effect but the sensitivity of volatility has a significantly positive effect on the implied cost of capital. After taking the incentives into account, we find that the significance of the impact from both agency problems still exists. Finally, we conclude that well-designed executive compensation should focus on reducing overinvestment and the sensitivity of volatility.
\end{abstract}

Keywords: Agency problems, Free cash flows, Overinvestment, Implied cost of capital.

\section{INTRODUCTION}

In corporate management, there are several potential problems in the principal-agent relationship. These are the so-called agency problems. Due to the conflict of interests between shareholders and managers, shareholders need to pay substantial costs to alleviate these problems, such as the costs of monitoring or of paying handsome executive compensation to provide incentives for managers to create firm values. In addition, these problems usually result in poor performance by the firm, either in market or accounting performance. From fundamental valuation theories, firm market value is affected by the firm's free cash flows and its cost of capital. ${ }^{1}$ In this paper, we focus on the issue of whether agency problems can affect the firm's cost of capital. That is, do a manager's decisions have a significant impact on the firm's financing costs?

High corporate cash holdings and overinvestment are the two main agency problems in the agency theory. Existing empirical evidence shows a positive relationship between these two agency problems. That is, overinvestment usually occurs in firms with high free cash flows (Richardson (2006)). Corporate cash holdings themselves, however, provide opportunities for managers to generate their own private benefits (Jensen (1986) and Myers and Rajan (1998)). Therefore, we focus on these two types of agency

*Address of correspondence to this author at the Department of Finance, National Chung Hsing University, No. 250, Kuo Kuang Rd., Taichung 40227, Taiwan; Tel: +886 42285 5571; Fax: +886 42285 6015;

E-mail: tyang1@nchu.edu.tw

JEL classification: G30; G32; G34.

${ }^{1}$ In this project, we only focus on the implied cost of equity instead of the overall cost of capital. However, we use implied cost of capital and implied cost of equity interchangeably in the context. problems in this paper. Because these two problems can change the firm's risk level according to market perspectives, under the assumptions of the efficient market hypothesis, the financial market should take these factors into account and reflect these changes in the firm's financing costs. Based on this hypothesis, we expect to observe a significant impact of agency problems on a firm's cost of capital.

Managerial incentives from executive compensation, however, have a substantial impact on agency problems. Aggarwal and Samwick (2006) show that both Tobin's $Q$ and firm's investment increase with the pay-for-performance sensitivity from stock and stock option compensation. ${ }^{2}$ This result implies that managers would increase the level of investment when they are given more stock-based compensation. Broussard, Buchenroth, and Pilotte (2004), by contrast, find evidence that incentives can reduce the overinvestment problem. Therefore, based on these results, we are interested in two questions about the effect of stock-based compensation on agency problems. First, how do incentives influence agency problems? Second, what is the impact of the interactions between executive compensation and agency problems, on the cost of capital?

Albuquerque and Wang (2008) and Garmaise and Liu (2005) suggest that strong shareholder rights can alleviate overinvestment problems, which, in turn, lower the cost of capital. Empirically, Chen, Chen, and Wei (2011) find that a significantly negative relationship between shareholder rights and the implied cost of equity, especially in the firms with more severe

\footnotetext{
${ }^{2}$ There is another implication in earlier research that is in contrast to Aggarwal and Samwick (2006). Bizjak, Brickley and Coles (1993) suggest that executive compensation contracts depend on the level of information asymmetry in each firm. They use traditional measures of growth opportunity, market-to-book ratio and $R \& D$ expenditures, as proxies for information asymmetry.
} 
problems of free cash flows. In addition, Byun, Kwak and Hwang (2008) find that sound corporate governance practices reduce the implied cost of equity capital through a reduction in agency problems and information asymmetry. The evidence shows that active corporate governance mechanism would reduce the cost of capital, but the passive corporate governance, such as executive compensation, has little evidence on this issue. Since the executive compensation is a part of corporate governance mechanism and has not been tested directly in the related literature, we focus on the impact of incentive effect from executive compensation on the agency problems and test whether this impact plays a role in the determination of the cost of capital. Because the incentives mainly come from stock-based compensation, we use the sensitivities of stock option and restricted stock with respect to stock price as incentive measures. ${ }^{3}$ In addition, because the volatility is also an important factor in the valuation of executive stock options, we use the sensitivity of stock option value to volatility as an alternative incentive measure in the empirical analysis.

From the empirical results, we find that free cash flows have a significant negative impact, but overinvestment has a significant positive impact on a firm's implied cost of capital. The implied cost of capital is estimated using the Ohlson and Juettner-Nauroth (2005) model (hereafter OJ model) and it significantly decreases with free cash flows asymmetrically with respect to the signs of overinvestment. Moreover, controlling for the impact of free cash flows, we find that the implied financing cost increases with the level of overinvestment. The positive impact of overinvestment on the implied cost of capital has no significant differences with respect to the sign of free cash flows. The result implies that investors would expect a lower expected return when firms have more financial flexibility, but a higher expected return when they have an overinvestment problem, which is consistent with the trade-off relation between risk and return. These results also suggest that management decisions to either reduce cash holdings, or invest beyond the expected level, would increase the firm's financing cost.

Assuming that stock, or stock option compensation, provides incentives for managers to create firm values,

\footnotetext{
${ }^{3} J$ ensen and Murphy (1990), Hall and Liebman (1998), and Baker and Hall (2004) point out that the main sources of incentives are from stock-based compensation rather than cash-based compensation.
}

we find that stock-based compensation can significantly alleviate some agency problems. First, the implied cost of capital decreases with the pay-forperformance sensitivities from stock-based compensations, either stock options or restricted stock or both. This implies that managers with more stock-based compensation would pursue the same interests as shareholders' and that decision would affect the future financing cost. In contrast to this explanation, the implied cost of capital significantly increases with the sensitivity to the changes in volatility. ${ }^{4}$ This is consistent with the trade-off relation between risk and return.

Second, there is little empirical evidence for the effect of executive compensation on agency problems but our results do shed light on this issue. We find that the incentives have different impacts on the problems of free cash flows and overinvestment. Because stockbased compensation provides incentives for CEOs to invest more, the free cash flows decrease with pay-forperformance sensitivity, especially in the firms with positive overinvestment. By the same token, however, we find that the overinvestment problem is positively related to the pay-for-performance sensitivity. This implies that the incentives make the overinvestment problem even worse. The level of overinvestment, however, decreases with the pay-for-performance sensitivity of the firms that have positive free cash flows.

Finally, the pay-for-performance sensitivities have no dominant effect relative to both agency problems in explaining the implied cost of capital. After taking these sensitivities and their interaction with both agency problems into account, the significance of both measures of agency problems still exist. Our results suggest some explanations for agency problems and the incentive effect.

First, free cash flows play two different roles in determining the firm's values: one is a proxy of financial flexibility and the other is an opportunity for managers to increase their private benefits. In our results, investors tend to view the free cash flows as a proxy of financial flexibility. Second, overinvestment is considered an agency problem and results in higher implied cost of capital due to the increase of risk level. Third, the pay-for-performance sensitivity has the expected function of alleviating the free cash flow

${ }^{4}$ We find that both sensitivities are highly correlated. To alleviate the multicollinearity in the regression analysis, we use the sensitivity of volatility that is orthogonal to the pay-for-performance sensitivity as the alternative incentive measure with respect to the change in volatility. 
agency problems, but tends to worsen the overinvestment agency problem.

In sum, the results help us to understand the connection between agency problems and financing costs and also contributes to the literature of agency theory and incentive mechanism from executive compensation. We briefly review the related literature in the next section. In Section 3, we summarize the sources of empirical data and the construction of free cash flows and overinvestment from accounting data. The empirical results are shown in Section 4. Section 5 provides the conclusion of the paper.

\section{LITERATURE REVIEW}

This paper is motivated by Stulz (1995) whose work discusses the cost of capital across countries from an agency perspective. The author argues that the cost of capital should differ across countries, because of the different levels of agency problems that result from different corporate governance. From fundamental pricing theory, the cost of capital should reflect the uncertainty of future cash flows. Therefore, arising from the uncertainty in each case, the cost of capital should be higher in firms with more serious agency problems, which in our paper are the firms with overinvestment or free cash flows. Stulz (1999), shows that the impact of agency costs on the cost of capital becomes less important when globalization is taken into account. The impact, however small, is still significant. Possible reasons for this impact are market efficiency or the home bias of the investor. Therefore, we expect that the agency problems will still have a substantial effect on the cost of capital in the U.S. economy.

Among all agency problems, overinvestment and free cash flows are the two main problems observed in the literature. In general, firms with the problem of overinvestment are those firms with high cash holdings (Richardson (2006) and Officer (2011)). The overinvestment problem occurs when managers invest beyond the optimal level so that the marginal benefit is less than the marginal cost in the investment. Hence, the overinvestment means that the managers invest in the projects that have negative net present value. We expect that this problem usually exists in firms with few investment opportunities. Many researchers use Tobin's $Q$ as a proxy for investment opportunities and implicitly assume that the lower Tobin's $Q$ is, the more possible it is to invest over the optimal level. Lang and Litzenberger (1989) support this notion by testing the announcement effect of dividend change and find that firms with lower Tobin's $Q$ have more positive announcement effects. Because Tobin's $Q$ is also used as a proxy for firm performance, it may cause problems when it comes to interpreting the effects of overinvestment.

For the problem of hoarding cash, corporate finance theory suggests that firms should return any redundant cash to shareholders. In reality, Jensen (1986) points out the agency problem of free cash flows, and finds evidence of unsuccessful acquisitions in the oil industry due to excessive free cash flows. Harford (1999) shows that firms with higher cash holdings tend to diversify their acquisitions and these acquisitions in general tend to destroy the firm's value. These results imply that firms with too many cash holdings tend to make aggressive progress in different business areas and this action can increase a firm's risk level. Kalcheva and Lins (2007) argue, however, that there exists little evidence for a link between the agency problem of free cash flows and the low firm values that exist in the literature. They also mention as a possible reason that external corporate governance in the U.S. economy may be strong enough that the hoarding of cash is not a systematic risk. ${ }^{5}$ In contrast, some theoretical and empirical findings show that cash holdings have a positive impact on firm values, that of financial flexibility, when the cost of underinvestment is high (Mikkelson and Partch (2003) and Almeida, Campello, and Weisbach (2004)). In this paper, therefore, we test whether investors take the agency problem of free cash flows into account, and how they consider the cash holdings of a firm in the determination of their expected returns.

Agency problems are highly correlated with corporate governance. Both external and internal corporate governance systems provide a monitoring function in management decisions. Another mechanism to solve agency problems occurs through executive compensation, especially stock-based compensation. Management ownership tends to align shareholder and management interests, thereby alleviating some agency problems. ${ }^{6}$ Morck, Shleifer, and Vishny (1988)

\footnotetext{
${ }^{5}$ The fundamental valuation theories present the idea that the increase of free cash flows and the increase of the cost of capital have a counter effect in the valuation of firms. Therefore, we test the impact of free cash flows on the cost of capital directly.

${ }^{6}$ Based on the survey in Core, Guay, and Larcker (2003), there is no consensus on how the stock-based compensation influences the firm performance. We, however, do not focus on firm performance but instead we look at the cost of capital, which is a main determinant for firm performance. Therefore, our empirical results would provide useful information regarding the relation between stock-based compensation and the cost of capital.
} 
argue that two effects exist between management ownership and firm performance: the convergence-ofinterests effect and the entrenchment effect. The latter effect dominates the former within the range of ownership between $5 \%$ and $25 \%$. McConnell and Servaes (1990) find similar results by using data about insider ownership. Core and Larcker (2002) find that both stock and accounting returns increase after firms adopt "target ownership plans." Based on these results, we expect stock-based compensation to affect the cost of capital substantially. Moreover, Mehran (1995) suggests that the main driver for managers to increase the value of the firm is the form, rather than the level, of their executive compensation. This finding is also consistent with our expectation that stock-based compensation would have an impact on the cost of capital and further influence the value of the firm.

We are interested in the relation between agency problems, executive compensation, and the cost of capital. Because executive compensation can align interests between shareholders and managers, the question arises: Can this kind of alignment significantly alleviate agency problems? There is little evidence in the literature to show the interactions between agency problems and executive compensation. In addition, we do not know how this interaction affects the cost of capital. Many researchers, however, seem to implicitly assume that executive compensation is what is being used to reduce agency problems. One of the main contributions of this paper is in providing empirical evidence that shows how these two factors interact in the U.S. economy and the influence of this interaction on the cost of financing a firm.

\section{METHODOLOGY AND DATA SUMMARY}

There are four empirical tests in this paper. First, we analyze the effect of agency problems, which are here defined as free cash flows and overinvestment, on the implied cost of capital. Second, we test the effect of the pay-for-performance sensitivities from stock-based compensation on the implied cost of capital. Third, we look at how incentive effects influence both agency problems. Finally, we will look at the impact of executive compensation on the relationship between agency problems and the implied financing cost. Estimating the implied cost of capital for the sample of U.S. public firms is a key point in this paper. To show convincing evidence for this relationship, we follow the existing literature and estimate the implied cost of capital using the OJ model ${ }^{7}$.

Ohlson and Juettner-Nauroth simply use two forthcoming earnings per share, eps $s_{1}$ and $e p s_{2}$, one forthcoming dividend per share, $d p s_{1}$, and short-term and long-term growth rates, $\alpha$ and $\beta$ respectively, to recover the current stock price, $P_{0}{ }^{8}$ The discount rate, $r_{e}$, in the recovery process is the measure of implied cost of capital. ${ }^{9}$ As Gode and Mohanram (2003) note, the fundamental valuation formula in the OJ model is

$$
\begin{aligned}
P_{0} & =\frac{e p s_{1}}{r_{e}-\beta}=\frac{e p s_{1}}{r_{e}}-\frac{e p s_{1}}{r_{e}}+\frac{e p s_{1}}{r_{e}-\beta} \\
& =\frac{e p s_{1}}{r_{e}}+\frac{\alpha \times e p s_{1}}{r_{e}\left(r_{e}-\beta\right)}
\end{aligned}
$$

Solving $r_{e}$ in the equation (1), the implied cost of capital is

$r_{e}=x+\sqrt{x^{2}+\frac{e p s_{1}}{P_{0}}(y-\beta)}$

where $x=0.5 \times\left(\beta+\frac{d p s_{1}}{P_{0}}\right), y=\frac{e p s_{2}-e p s_{1}}{e p s_{1}}$.

Following Gode and Mohanram (2003), we set the long-term growth rate, $\beta$, equal to the yield on 10-year Treasury bond minus $3 \%$. As for $d p s_{1}$, it is equal to eps ${ }_{1}$, multiplying the payout ratio. ${ }^{10}$ We estimate the implied cost of capital for each firm at the end of June each year.

Next, we measure two agency problems for each firm: free cash flows and overinvestment. Following the approach in Richardson (2006), we estimate free cash flows and overinvestment simultaneously by using

\footnotetext{
${ }^{7}$ There are many approaches to estimate the implied cost of equity (Botosan and Plumlee (2005); Easton and Monahan(2005); Hail and Leuz (2006), (2009); Chen, Chen, and Wei (2011)), and there is no unanimous approach in the estimation. To alleviate the problem of measurement error, we conduct the same tests with the cost of equity from the market model and the results are qualitatively the same. In addition, $\mathrm{Li}$ (2015) show that four different models as suggested by Claus and Thomas (2001), Gebhardt, Lee, and Swaminathan (2001), Ohlson and Juettner-Nauroth (2005), Easton (2004) and their arithmetic mean are highly correlated with each other.

${ }^{8}$ Short-term growth rate is defined by $\alpha=\left(e p s_{2}-e p s_{1}-r_{e}\left(e p s_{1}-d p s_{1}\right)\right) / e p s_{1}$ and $\beta$ is a constant perpetual growth rate in Ohlson and Juettner-Nauroth (2005) and Gode and Mohanram (2003).

${ }^{9}$ Here, we briefly summarize the steps to estimate the cost of capital. Interested readers can refer to Ohlson and Juettner-Nauroth (2005) or Gode and Mohanram (2003).

${ }^{10}$ Following Gode and Mohanram (2003), we set the payout ratio equal to current dividends divided by current earnings when current earnings are positive. Otherwise we assume the payout ratio equal to current dividends divided by $6 \%$ of total assets.
} 
accounting information. The free cash flows are the cash flows generated from assets in place that exceed the cash needed for future expected investment. Future expected investment is the expected investment that varies with growth opportunities and other characteristic factors of the firm. Based on the premise of free cash flows and overinvestment, we can estimate both measures using the following steps.

First, the cash flows from assets in place, $C F_{A I P}$, is the operating cash flows, OCF, subtracted from the investment of maintaining assets in place, $I_{\text {AIP }}$, plus the expense of research and development, $R \& D$, which is

$C F_{A I P}=O C F-I_{A I P}+R \& D$.

The free cash flows, $F C F$, are $C F_{A I P}$ minus the expected new investment, $\hat{I}_{N E W}$, which is

$F C F=C F_{A I P}-\hat{I}_{N E W}$.

Second, the expected new investment is estimated from the fitted value of the following regression,

$I_{N E W}=\alpha+\gamma_{1} \frac{V_{A I P}}{P_{t-1}}+\gamma X_{t-1}+I_{\varepsilon}$

$I_{N E W}$ is equal to the total investment minus $I_{A I P}, V_{A I P}$ is the value from assets in place, $P$ is the firm's market price, $X$ is a vector of other variables of firm characteristics, which includes leverage, size, age of the firm, lagged stock return, and lagged new investment. ${ }^{11}$ In the regression, we denote $\frac{V_{A I P}}{P_{t-1}}$ as VP and it represents the firm's growth opportunity. Finally, $I_{\varepsilon}$ is the residual term in the regression and is also the measure for overinvestment. Therefore, we can measure free cash flows and overinvestment simultaneously from the equations (4) and (5).

The second test is that of the incentives from stockbased compensation. We look at executive compensation in the ExecuComp database, to find an incentive measure. In this paper, we limit our focus to executive compensation for CEOs. ${ }^{12}$ The incentives mainly come from the managerial holding of firm stock and stock options. The incentives from stock can be computed using data in the database about a

\footnotetext{
${ }^{11}$ The method of estimating the value from assets in place follows Richardson (2006). We summarize the method in Appendix I.

${ }^{12}$ The compensation affects the major officers who can influence the process of making decisions, but CEOs in general have a major effect on the final decisions.
}

manager's stock holding. The incentives from stock options, however, are more complex than the stock of the firm. The stock grants in different years should be considered the same from the stock perspective but stock option grants in different years are different due to different exercise prices and maturities. In addition, because the ExecuComp database only has compensation data details for the firm's current fiscal year, it is difficult to abstract accurate incentives from the data on managerial stock options, especially the out-of-the-money options.

Core and Guay (2002) provide a useful method for estimating the sensitivities of option portfolios to stock price and stock return volatility using data from the current year. ${ }^{13}$ They estimate these sensitivities for current, and previous, option grants separately by applying the Black-Scholes model. The pay-forperformance sensitivity, PPS, is the partial derivative of the Black-Scholes option value with respect to the stock price. The PPS of the current option grant can be estimated by using detailed data for the current fiscal year. For the previously granted options, we can estimate the PPS only for in-the-money options by implied exercise prices from unexercisable and exercisable options. Broussard, Buchenroth, and Pilotte (2004) apply the same method to recover the implied exercise price, which is

Implied exercise price $=P_{0}-\left(\frac{\text { ITMEX+ITMUN }}{\mathrm{UXEX}+\mathrm{UXUN}}\right)$,

where $P_{0}$ is the current stock price, and ITMEX and ITMUN are the intrinsic value of in-the-money exercisable and unexercisable options respectively. UXEX and UXUN are the total number of unexercised exercisable and unexercisable options respectively. For the maturity of previously granted options, following Core and Guay (2002), we assume the unexercisable options have a maturity three years longer than that of exercisable options. The unexercisable options have a maturity that is the same as that of the most recent option grant. ${ }^{14}$ Because the other variables in the Black-Scholes model, such as expected stock return volatility, and expected dividend yield, are stable across different option grants, we use the same inputs as those of the most recent options.

\footnotetext{
${ }^{13}$ Core and Guay (2002) show in their paper that these estimated incentive measures capture more than $99 \%$ of the variation in option portfolio value and sensitivities. The explanatory power is also more than $95 \%$ in their sample.

${ }^{14}$ If there is no most recent option grant available, following Core and Guay (2002), we use a nine-year maturity for unexercisable options and a six-year maturity for exercisable ones.
} 
In this paper, we use all data available in the databases about public firms in the U.S. to perform these four tests. The data range is from 1994 to 2009. All accounting data comes from the Compustat database. Other variables used to estimate the implied cost of capital, such as earnings and dividends, are from the $1 / B / E / S$ database. In addition, we collect current stock prices from the CRSP database. Because financial institutions have different regular operations than other firms, we exclude all financial firms that have SIC codes in the 6000 to 6999 range.

The Compustat database provides all the data we need for the estimation of free cash flows and overinvestment. OCF is net cash flows from operating activities with data item $308, I_{A I P}$ is the amortization and depreciation expense with data item 125 , and $R \& D$ is the research and development expenditure with data item 46. To generate the fitted value of new investment, we need the stock price, the book value of total assets, the earnings, the dividends, and the cost of capital. Following Richardson (2006), we include firm characteristic variables: the leverage (LEV), the firm size (SIZE), the firm age (AGE), the stock of cash (CASH), the past stock returns (STR), the prior firm level investment (NEWINV), and the control variables for the year and industrial fixed effects in our estimation of the expected investment. To alleviate the effect of outliers in the following analysis, we exclude the observations where free cash flows or overinvestment exceeds one in absolute value, and where their expected stock return exceeds $200 \%$. The final sample covers 9,419 firm-years. We summarize the statistics of two estimated agency problems and other variables in Table 1.

We find in Table 1 that about half of the firms in our sample have an agency problem. Roughly $50 \%$ of the firms in our sample have positive free cash flows and $45 \%$ have positive overinvestment. Therefore, these two problems are not rare events in our sample. The LEV is the book value of debt ratio and it ranges from 4.32 to 0 . Due to the negative book value of total equity, we have 90 observations with LEV $>1$. Most of the firms have a positive book value of total equity. In addition, the mean and median of firm age is around 11 years for those firms that are listed in CRSP, which implies our sample is not overly concentrated in either old or new firms. Because we use these variables in a regression analysis, it is important to check their correlations. We summarize the correlation matrix in Table 2.

The first thing we notice is the correlation between overinvestment and other variables other than cost of capital. Because the measure of overinvestment is the residual of the regression of new investment, following the econometric theory of ordinary least square regression, the independent variables should be orthogonal to the residual terms. The variables that have zero correlation with overinvestment are independent variables or control variables in the regression of new investment. Due to this result, we do not add these variables as control variables in the regression of overinvestment in the later analysis. There is no highly correlated relationship among these

Table 1: Summary Statistics

\begin{tabular}{|c|c|c|c|c|c|}
\hline Variable & Mean & Median & Standard Deviation & P90 & P10 \\
\hline \hline FCF & 0.0109 & 0.0105 & 0.0997 & 0.1239 & -0.0968 \\
\hline OVERINV & 0.0001 & -0.0136 & 0.0852 & 0.0916 & 0.0771 \\
\hline ICC & 0.0619 & 0.0519 & 0.0564 & 0.9381 & 0.0026 \\
\hline VP & 0.5119 & 0.4536 & 0.3757 & 0.4082 & $<.4645$ \\
\hline LEV & 0.1761 & 0.1415 & 0.1877 & 3.5264 & 0.0000 \\
\hline CASH & 0.1797 & 0.1112 & 0.1878 & 8.2819 & 1.0986 \\
\hline AGE & 2.4141 & 2.3979 & 0.8920 & 1.8451 & 0.2225 \\
\hline SIZE & 5.8686 & 5.7259 & 0.1164 & -0.0001 \\
\hline NEWINV & 0.0981 & 0.0744 & 0.6724 \\
\hline
\end{tabular}

We use the public firms that have data available in CRSP and Compustat databases from 1994 to 2009. There are 9,419 firm-years in our sample. FCF and OVERINV are the measures of free cash flows and overinvestment respectively, which are estimated following Richardson (2006). ICC is the implied cost of capital from the Ohlson-Juettner model. VP is a measure of growth opportunity and it is the ratio of the value of assets in place to current market price, LEV is the leverage ratio, CASH is the sum of the cash balance and short term investments deflated by total assets, AGE is the log of the number of years the firm has been listed in CRSP database, SIZE is the firm size, which is the log of total asset, and NEWINV is the total investment net of the investment of maintaining the assets in place. 
Table 2: Correlation Matrix

\begin{tabular}{|c|c|c|c|c|c|c|c|c|c|}
\hline Variable & FCF & OVERINV & ICC & VP & LEV & CASH & AGE & SIZE & NEWINV \\
\hline FCF & 1 & & & & & & & & \\
\hline OVERINV & -0.0328 & 1 & & & & & & & \\
\hline ICC & -0.0960 & -0.0053 & 1 & & & & & & \\
\hline VP & 0.3585 & 0.0000 & -0.1376 & 1 & & & & & \\
\hline LEV & 0.0172 & 0.0000 & -0.0481 & 0.0228 & 1 & & & & \\
\hline $\mathrm{CASH}$ & -0.3612 & 0.0000 & 0.1370 & -0.3473 & -0.3474 & 1 & & & \\
\hline AGE & 0.2190 & 0.0000 & -0.1144 & 0.1981 & 0.0918 & -0.3140 & 1 & & \\
\hline SIZE & 0.2998 & 0.0000 & -0.1098 & 0.1290 & 0.1965 & -0.2487 & 0.3123 & 1 & \\
\hline NEWINV & -0.4691 & 0.0000 & 0.0765 & -0.3412 & -0.0801 & 0.3512 & -0.1970 & -0.1854 & 1 \\
\hline
\end{tabular}

We use the public firms that have data available in CRSP and Compustat databases from 1994 to 2009. There are 9,419 firm-years in our sample. FCF and OVERINV are the measures of free cash flows and overinvestment respectively, which are estimated following Richardson (2006). ICC is the implied cost of capital from the Ohlson-Juettner model. VP is a measure of growth opportunity and it is the ratio of the value of assets in place to current market price, LEV is the leverage ratio, CASH is the sum of the cash balance and short term investments deflated by total assets, AGE is the log of the number of years the firm has been listed in CRSP database, SIZE is the firm size, which is the log of total asset, and NEWINV is the total investment net of the investment of maintaining the assets in place.

variables other than two measures of agency problems. Based on the previous studies (Gode and Mohanran (2003); Ali, Hwang, and Trombley (2003); Barron, Byard, Kile, and Riedl (2002); Botosan and Plumlee, (2005)), we add VP, LEV, CASH, AGE, SIZE, Lag(STR) and NEWINV as controls variables in the regression analysis. VP is proxy for firm's growth opportunities, which is important to firm's investment decisions and cash holding policy. LEV is used to control for the firm's financial decisions and SIZE is used to control for the firm's information environment. CASH and NEWINV are the proxy for firm's financial flexibility and investment plan respectively. AGE is the proxy for the stage of firm's life cycle. Finally, due to the trade-off relationship between risk and return, we use Lag(STR) to control for stock price variability.

\section{EMPIRICAL RESULTS}

Based on the measures of two agency problems in Richardson (2006), we can test the relation between the implied cost of capital and the agency problems. In the existing literature, similar tests are performed using studies of events such as mergers and acquisitions or dividend initiations. In this paper, we test the relation directly by using accounting data and stock returns, which is one of our contributions to the literature.

\subsection{The Effect of Agency Problems}

From the viewpoint of asset pricing theories, the risk caused by agency problems should belong to firmspecific risk, which should not be reflected in the expected return of each firm. If this type of risk, however, generally exists in each firm and systematically influences the firm's implied cost of capital, investors should take the risk into account in the valuation of a firm. We focus on this issue in the first empirical test and summarize the regression results in Table 3.

From Table 3, we find that the implied cost of capital decreases with free cash flows but increases with overinvestment. In addition, the impacts of free cash flows on the implied cost of capital are asymmetric with respect to the sign of overinvestment. These results imply that there are economic explanations for the effect of the agency problems. First, financial flexibility is an important factor in corporate finance, especially when firms have substantial growth opportunities. ${ }^{15}$ Therefore, the free cash flows have a significant negative impact on the implied cost of capital. This suggests that investors put more emphasis on financial flexibility rather than on the possibility of abuse of these free cash flows. Second, the implied cost of capital increases with overinvestment, which implies that the intention of empire building raises the firm's financial costs, especially in the equity market. ${ }^{16}$ The impacts of both agency problems are significant regardless of year and industry dummies.

\footnotetext{
${ }^{15}$ Myers (1984) and Myers and Majluf (1984) suggest that financial flexibility can prevent the negative signaling in equity financing.

${ }^{16}$ The overinvestment measure in the regressions is the portion of overinvestment measure from Richardson (2006) that is orthogonal to the free cash flows.
} 
Table 3: Regression of Implied Cost of Equity on Free Cash Flow and Overinvestment

\begin{tabular}{|c|c|c|c|c|}
\hline Independent variable & I & II & III & IV \\
\hline FCF & $\begin{array}{l}-0.088 \\
(-8.99)^{\cdots}\end{array}$ & $\begin{array}{c}-0.099 \\
(-9.50)^{\cdots}\end{array}$ & $\begin{array}{c}-0.110 \\
(-9.46)^{*}\end{array}$ & $\begin{array}{l}-0.123 \\
(-8.94)^{* \cdots}\end{array}$ \\
\hline EOVERINV & $\begin{array}{c}0.030 \\
(3.64)^{\cdots *}\end{array}$ & $\begin{array}{c}0.034 \\
(4.00)^{-*}\end{array}$ & $\begin{array}{c}0.034 \\
(2.99)^{* *}\end{array}$ & $\begin{array}{c}0.042 \\
(3.61)^{* *}\end{array}$ \\
\hline DFCFOVER & & & $\begin{array}{l}-0.006 \\
(-0.33)\end{array}$ & $\begin{array}{l}-0.015 \\
(-0.77)\end{array}$ \\
\hline DOVERFCF & & & $\begin{array}{c}0.047 \\
(2.21)^{*}\end{array}$ & $\begin{array}{c}0.049 \\
(2.17)^{*}\end{array}$ \\
\hline VP & $\begin{array}{c}0.018 \\
(7.84)^{* *}\end{array}$ & $\begin{array}{c}0.021 \\
(8.79)^{\cdots *}\end{array}$ & $\begin{array}{c}0.018 \\
(7.86)^{\cdots}\end{array}$ & $\begin{array}{c}0.021 \\
(8.82)\end{array}$ \\
\hline LEV & $\begin{array}{c}0.030 \\
(5.74)^{* *}\end{array}$ & $\begin{array}{c}0.034 \\
(5.71)^{* * *}\end{array}$ & $\begin{array}{c}0.030 \\
(5.64)^{\cdots *}\end{array}$ & $\begin{array}{c}0.034 \\
(5.62)^{* * *}\end{array}$ \\
\hline $\mathrm{CASH}$ & $\begin{array}{c}0.020 \\
(5.09)^{-*}\end{array}$ & $\begin{array}{l}0.004 \\
(0.97)\end{array}$ & $\begin{array}{c}0.020 \\
(5.17)^{-\cdots}\end{array}$ & $\begin{array}{l}0.005 \\
(1.08)\end{array}$ \\
\hline AGE & $\begin{array}{l}-0.002 \\
(-3.02)^{\cdots *}\end{array}$ & $\begin{array}{c}-0.003 \\
(-4.21)^{\cdots}\end{array}$ & $\begin{array}{c}-0.002 \\
(-2.91)^{\cdots}\end{array}$ & $\begin{array}{l}-0.003 \\
(-4.11)\end{array}$ \\
\hline SIZE & $\begin{array}{c}-0.006 \\
(-13.64)^{\cdots}\end{array}$ & $\begin{array}{c}-0.007 \\
(-16.75)^{* * *}\end{array}$ & $\begin{array}{c}-0.006 \\
(-13.56)^{* * *}\end{array}$ & $\begin{array}{c}-0.007 \\
(-16.68)\end{array}$ \\
\hline Lag(STR) & $\begin{array}{c}-0.010 \\
(-6.08)^{-*}\end{array}$ & $\begin{array}{l}-0.009 \\
(-5.80)^{\cdots}\end{array}$ & $\begin{array}{l}-0.010 \\
(-6.12)^{\cdots}\end{array}$ & $\begin{array}{c}-0.009 \\
(-5.85)^{\cdots *}\end{array}$ \\
\hline NEWINV & $\begin{array}{l}-0.002 \\
(-0.31)\end{array}$ & $\begin{array}{l}0.001 \\
(0.23)\end{array}$ & $\begin{array}{l}-0.005 \\
(-0.78)\end{array}$ & $\begin{array}{l}-0.001 \\
(-0.18)\end{array}$ \\
\hline CON & $\begin{array}{c}0.084 \\
(26.64)\end{array}$ & $\begin{array}{c}0.078 \\
(16.99)^{\cdots}\end{array}$ & $\begin{array}{c}0.084 \\
(26.56)\end{array}$ & $\begin{array}{c}0.078 \\
(16.95)^{\cdots}\end{array}$ \\
\hline Year Dummy & No & Yes & No & Yes \\
\hline Industry Dummy & No & Yes & No & Yes \\
\hline Adjusted $\mathrm{R}^{2}$ & 0.108 & 0.174 & 0.109 & 0.175 \\
\hline
\end{tabular}

The dependent variable in the regressions is the implied cost of capital, ICC, estimated from the Ohlson-Juettner model. FCF is the measure of free cash flow estimated by subtracting expected investment from cash flows from assets in place. EOVERINV is the measure of overinvestment orthogonal to FCF. DFCFOVER is the interaction variable between the dummy variable of positive free cash flows and the measure of overinvestment. DOVERFCF is the interaction variable between the dummy variable of the positive overinvestment and free cash flow. VP is a measure of growth opportunity and it is the ratio of the value of assets in place to current market price, LEV is the leverage ratio, CASH is the sum of the cash balance and short term investments deflated by total assets, AGE is the log of the number of years the firm has been listed in CRSP database, Lag(STR) is the lagged stock return, SIZE is the firm size, which is the log of total asset, and NEWINV is the total investment net of the investment of maintaining the assets in place. CON is the constant. There are 9,419 firm-years in our sample. We report NewerWest T-statistics in parentheses. ", , and indicate significance levels of $1 \%, 5 \%$, and $10 \%$ respectively.

It is worthwhile noting the interaction term between the dummy of overinvestment and free cash flows. In regressions III and IV, the impact of free cash flows is not symmetric with respect to the overinvestment level. When the firms have investment expenses greater than their expected levels, the more free cash flows they have, the higher their implied cost of capital would be. Even though free cash flows signal a certain financial flexibility, their impact on future financial costs depends on the firm's investment decisions. In contrast, the status of free cash flows, proxied by the dummy of positive free cash flows, does not significantly affect the impact of overinvestment on the implied cost of capital.
In sum, we find that the agency problem of free cash flows, on average, does not raise future financial costs significantly. Overinvestment, however, increases the implied cost of capital significantly, which is consistent with the findings of Stulz (1995), Richardson (2006), and Officer (2011). Overall, investors pay attention to the agency problems we analyzed in the paper. It is not easy for investors to identify abuses in free cash flows. Firms, however, are usually in dire need of internal financing resources. Financial flexibility signaling- by free cash flows- plays the major role in explaining the implied cost of capital. In contrast, estimating overinvestment by an analysis of accounting 
data is easier. In addition to its own significantly positive impact on future financing costs, it also diminishes the benefit of financial flexibility from free cash flows.

\subsection{The Impact of Incentives}

Before analyzing the effect of stock-based compensation on the relation between the implied cost of capital and the agency problems, we need to understand how the incentives influence the implied cost of capital. The incentives from stock-based compensation come from at least two different sources: sensitivities of executive compensation to stock price and stock return volatility. The former, which is commonly mentioned in the literature of stock options, is the pay-for-performance sensitivity (Jensen and Murphy (1990), Hall and Murphy (2002), and Hall and Knox (2004)). This sensitivity is used to measure the change in a manager's stock-based wealth that is a direct response to a change in stock price. The latter sensitivity is a measure of the wealth change resulting from changes in stock return volatility. Both incentives might change investment decisions, and thus influence the risk level of the firm's operation. The regression results of implied cost of capital on incentives are summarized in Table 4 . We classify the pay-forperformance sensitivity in three ways: stock options,

Table 4: Regression of Implied Cost of Equity on Incentive Measure

\begin{tabular}{|c|c|c|c|c|c|}
\hline Independent variable & I & II & III & IV & V \\
\hline TPPS & $\begin{array}{c}-3.413 \\
(-8.02)^{* * *}\end{array}$ & & & & $\begin{array}{l}-3.169 \\
(-8.25)^{\text {*** }}\end{array}$ \\
\hline SOPPS & & $\begin{array}{c}-3.746 \\
(-5.63)^{\star * *}\end{array}$ & & & \\
\hline RSPPS & & & $\begin{array}{l}-3.955 \\
(-6.01)^{* \star \star}\end{array}$ & & \\
\hline SOPPV & & & & $\begin{array}{l}-2.597 \\
(-4.75)^{\text {*** }}\end{array}$ & \\
\hline SPOVRED & & & & & $\begin{array}{c}3.591 \\
(3.44)^{n * *}\end{array}$ \\
\hline VP & $\begin{array}{c}0.029 \\
(9.20)^{* * *}\end{array}$ & $\begin{array}{c}0.029 \\
(9.15)^{* \star *}\end{array}$ & $\begin{array}{c}0.030 \\
(9.68)^{* \star *}\end{array}$ & $\begin{array}{c}0.030 \\
(9.35)^{\star \star \star}\end{array}$ & $\begin{array}{c}0.030 \\
(9.34)^{* * * *}\end{array}$ \\
\hline LEV & $\begin{array}{c}0.022 \\
(7.02)^{* * *}\end{array}$ & $\begin{array}{c}0.023 \\
(7.12)^{* \star *}\end{array}$ & $\begin{array}{c}0.019 \\
(6.64)^{* \star *}\end{array}$ & $\begin{array}{c}0.021 \\
(6.94)^{* \star *}\end{array}$ & $\begin{array}{c}0.020 \\
(6.57)^{* * *}\end{array}$ \\
\hline CASH & $\begin{array}{l}0.005 \\
(1.14)\end{array}$ & $\begin{array}{l}0.005 \\
(1.20)\end{array}$ & $\begin{array}{l}0.003 \\
(0.71)\end{array}$ & $\begin{array}{l}0.004 \\
(0.92)\end{array}$ & $\begin{array}{l}0.005 \\
(1.01)\end{array}$ \\
\hline AGE & $\begin{array}{l}-0.002 \\
(-2.55)^{* *}\end{array}$ & $\begin{array}{l}-0.002 \\
(-2.25)^{* *}\end{array}$ & $\begin{array}{l}-0.002 \\
(-2.46)^{* *}\end{array}$ & $\begin{array}{l}-0.002 \\
(-2.15)^{* *}\end{array}$ & $\begin{array}{l}-0.002 \\
(-2.61)^{* * *}\end{array}$ \\
\hline SIZE & $\begin{array}{c}-0.004 \\
(-7.43)^{* * *}\end{array}$ & $\begin{array}{c}-0.004 \\
(-6.92)^{\star \star \star}\end{array}$ & $\begin{array}{c}-0.003 \\
(-6.93)^{* * *}\end{array}$ & $\begin{array}{c}-0.003 \\
(-6.53)^{* * *}\end{array}$ & $\begin{array}{l}-0.004 \\
(-7.30)^{* * *}\end{array}$ \\
\hline Lag(STR) & $\begin{array}{c}-0.011 \\
(-8.96)^{* * *}\end{array}$ & $\begin{array}{c}-0.011 \\
(-8.76)^{* * *}\end{array}$ & $\begin{array}{c}-0.011 \\
(-8.67)^{* * *}\end{array}$ & $\begin{array}{l}-0.011 \\
(-8.59)^{* * *}\end{array}$ & $\begin{array}{c}-0.011 \\
(-8.72)^{* * *}\end{array}$ \\
\hline NEWINV & $\begin{array}{l}0.009 \\
(1.45)\end{array}$ & $\begin{array}{l}0.009 \\
(1.53)\end{array}$ & $\begin{array}{c}0.011 \\
(1.77)^{*}\end{array}$ & $\begin{array}{l}0.010 \\
(1.69)^{*}\end{array}$ & $\begin{array}{l}0.010 \\
(1.61)\end{array}$ \\
\hline CON & $\begin{array}{c}0.054 \\
(9.74)^{* * *}\end{array}$ & $\begin{array}{c}0.051 \\
(9.13)^{* * *}\end{array}$ & $\begin{array}{c}0.051 \\
(9.36)^{* * *}\end{array}$ & $\begin{array}{c}0.049 \\
(8.78)^{* \star *}\end{array}$ & $\begin{array}{c}0.054 \\
(9.68)^{* * *}\end{array}$ \\
\hline Adjusted $\mathrm{R}^{2}$ & 0.214 & 0.209 & 0.211 & 0.207 & 0.214 \\
\hline
\end{tabular}

The dependent variable in the regressions is the implied cost of capital, ICC, estimated from Ohlson-Juettner model. SOPPS and RSPPS are pay-for-performance sensitivities of stock options and restricted stock respectively and they are estimated based on Core and Guay (2002). TPPS is the sum of SOPPS and RSPPS. SOPPV is the sensitivity of stock option to stock return volatility. SPOVRED is the SOPPV orthogonal to TPPS. All sensitivities are deflated by total assets. VP is a measure of growth opportunity and it is the ratio of the value of assets in place to current market price, LEV is the leverage ratio, CASH is the sum of the cash balance and short term investments deflated by total assets, AGE is the log of the number of years the firm has been listed in CRSP database, Lag(STR) is the lagged stock return, SIZE is the firm size, which is the log of total asset, and NEWINV is the total investment net of the investment of maintaining the assets in place. Because we merge the original sample with data in the ExecuComp database, the final sample in this test covers 4,849 observations. We report Newer-West Tstatistics in parentheses. " ," , and "indicate significance levels of $1 \%, 5 \%$, and $10 \%$ respectively. 
restricted stock, and the sum of both. In addition, we only estimate the sensitivity to volatility for stock options.

The results in regressions I, II, and III show a consistent pattern. The implied cost of capital decreases with pay-for-performance sensitivities. The coefficients are all significant under one percent. One major reason for granting stock-based compensation is to alleviate the conflicts of interest between management and shareholders. Therefore, we expect that efficient executive compensation should reduce the future financing cost, because of this alignment of interests. Executive compensation also induces managers to maximize the value of their firm. Based on fundamental valuation theory, managers can increase the value of a firm by creating more cash flows, or by reducing the cost of capital. In our results, we find that firms with more incentives from stock-based compensation have a lower implied cost of capital. This result supports our theory on the effect of stock-based compensation, and of incentives measured by the payfor-performance sensitivity.

In addition to the pay-for-performance sensitivity, the sensitivity to volatility also has a significantly negative impact on the implied cost of capital. This is inconsistent with the trade-off between risk and return. Of course, that assumes that managers intend to increase the risk of their investments. Financing costs should rise when investors identify such an intention. In regression IV, however, the result is counter-intuitive. That is, the incentive to increase firm's volatility significantly reduces the firm's implied cost of capital. Empirically, some researchers find that the risk level increases when the incentive to maximize stock price increases. ${ }^{17}$ The result suggests that managers with more stock-based compensation would invest more, relative to others, and this action would increase the firm's risk level. Moreover, this expectation is consistent with empirical evidence in the literature of mergers and acquisitions. Cai and Vijh (2007) show that managers with higher stock holdings tend to make acquisitions with higher premiums, and make acquisitions in different business areas by paying with stock. Therefore, we expect a positive influence from the sensitivity of volatility on the financing cost. How to explain the result of regression IV?

\footnotetext{
${ }^{17}$ Guay (1999) shows some evidence that firm risk increases when the firm provides higher risk-taking incentives, which is the convexity of executive compensation. The author also finds that stock return volatility is positively related to the convexity.
}

We suspect that both incentives may share some common component in explaining the implied cost of capital. The correlation coefficient between two sensitivities is higher than $0.8 .{ }^{18}$ To take into account the effects of both sensitivities, we run a regression analysis of the sensitivity of volatility on the pay-forperformance sensitivity and take the residual as the measure of the incentive to increase volatility that is orthogonal to the pay-for-performance sensitivity. In regression $\mathrm{V}$, we find the intuitive result that the incentive to increase volatility significantly raises the implied cost of capital and the pay-for-performance sensitivity has the original impact. ${ }^{19}$ This result is consistent with the trade-off relation between risk and return, and also supports the expectation that managers with more stock-based compensation would invest more, and thus increase the risk level of the firm.

\subsection{Incentives and Agency Problems}

From the previous results, we show that both free cash flows, and the pay-for-performance sensitivity, have significant negative impacts on the implied cost of capital. In the existing literature, however, there is little evidence to show the efficiency of incentives on alleviating the agency problems. ${ }^{20}$ Because we estimate both agency problems of free cash flows and overinvestment directly from accounting data in this paper, we have a good opportunity to test how these incentives influence both problems. First, we summarize the impact of incentive effects on the agency problem of free cash flows in Table 5 . In regressions I, III, and IV, both incentives- TPPS and SPOVRED- have significantly negative impacts on free cash flows. This result is consistent with the previous explanation that stock-based compensation offers incentives for managers to invest more and, by doing so, to lower free cash flows. We can explain this result in two ways. First, the investment decisions induced by both incentives significantly alleviate the problem of free cash flows. Second, the incentives tighten the

\footnotetext{
${ }^{18}$ The correlation coefficient is 0.85 between total pay-for-performance sensitivity and the sensitivity to volatility. The sensitivity to volatility has a correlation coefficient of 0.97 to the pay-for-performance sensitivity from stock options only.

${ }^{19}$ The qualitative result does not change when we use pay-for-performance sensitivity from stock option compensation instead of total stock-based compensation.

${ }^{20}$ Yermack (1995) finds that few agency or financial contracting theories can explain the pattern of stock option grants in the U.S. economy. In our paper, however, we look at how stock-based compensation influences both agency problems.
} 
Table 5: The Impact of Sensitivity of Stock-Based Compensation on Free Cash Flows

\begin{tabular}{|c|c|c|c|c|}
\hline Independent variable & $\mathbf{I}$ & II & III & IV \\
\hline TPPS & $\begin{array}{l}-13.495 \\
(-3.85)^{* * *}\end{array}$ & $\begin{array}{c}-6.089 \\
(-2.63)^{* * *}\end{array}$ & $\begin{array}{l}-16.590 \\
(-4.77)^{* * *}\end{array}$ & $\begin{array}{l}-18.288 \\
(-4.58)^{* \star *}\end{array}$ \\
\hline DOVERTPS & & $\begin{array}{l}-15.589 \\
(-2.98)^{* * *}\end{array}$ & & $\begin{array}{l}3.086 \\
(0.75)\end{array}$ \\
\hline SPOVRED & & & $\begin{array}{l}-43.765 \\
(-4.00)^{\star * *}\end{array}$ & $\begin{array}{l}-47.037 \\
(-4.03)^{\star \star * *}\end{array}$ \\
\hline VP & $\begin{array}{l}-0.010 \\
(-1.00)\end{array}$ & $\begin{array}{l}-0.015 \\
(-1.99)^{*}\end{array}$ & $\begin{array}{l}-0.016 \\
(-2.42)^{* *}\end{array}$ & $\begin{array}{l}-0.016 \\
(-2.35)^{* *}\end{array}$ \\
\hline LEV & $\begin{array}{c}-0.075 \\
(-4.39)^{* * * *}\end{array}$ & $\begin{array}{c}-0.068 \\
(-4.75)^{* * *}\end{array}$ & $\begin{array}{c}-0.056 \\
(-4.52)^{* * *}\end{array}$ & $\begin{array}{l}-0.056 \\
(-4.51)^{* * *}\end{array}$ \\
\hline $\mathrm{CASH}$ & $\begin{array}{l}0.012 \\
(1.12)\end{array}$ & $\begin{array}{l}0.015 \\
(1.37)\end{array}$ & $\begin{array}{c}0.020 \\
(1.81)^{*}\end{array}$ & $\begin{array}{c}0.020 \\
(1.81)^{*}\end{array}$ \\
\hline AGE & $\begin{array}{c}0.004 \\
(1.94)^{*}\end{array}$ & $\begin{array}{l}0.004 \\
(2.16)^{* *}\end{array}$ & $\begin{array}{c}0.004 \\
(2.28)^{* *}\end{array}$ & $\begin{array}{c}0.004 \\
(2.26)^{* *}\end{array}$ \\
\hline SIZE & $\begin{array}{c}0.005 \\
(4.37)^{* * *}\end{array}$ & $\begin{array}{c}0.005 \\
(4.37)^{* \star *}\end{array}$ & $\begin{array}{c}0.005 \\
(4.04)^{\star \star \star *}\end{array}$ & $\begin{array}{c}0.005 \\
(4.03)^{\star \star *}\end{array}$ \\
\hline Lag(STR) & $\begin{array}{l}0.006 \\
(1.61)\end{array}$ & $\begin{array}{c}0.006 \\
(1.66)^{*}\end{array}$ & $\begin{array}{l}0.003 \\
(0.83)\end{array}$ & $\begin{array}{l}0.002 \\
(0.77)\end{array}$ \\
\hline NEWINV & $\begin{array}{l}-0.023 \\
(-0.83)\end{array}$ & $\begin{array}{l}-0.025 \\
(-1.00)\end{array}$ & $\begin{array}{l}-0.034 \\
(-1.46)\end{array}$ & $\begin{array}{l}-0.035 \\
(-1.47)\end{array}$ \\
\hline CON & $\begin{array}{l}0.006 \\
(0.53)\end{array}$ & $\begin{array}{l}0.009 \\
(0.79)\end{array}$ & $\begin{array}{l}0.011 \\
(0.96)\end{array}$ & $\begin{array}{l}0.011 \\
(0.94)\end{array}$ \\
\hline Adjusted $\mathrm{R}^{2}$ & 0.157 & 0.168 & 0.190 & 0.190 \\
\hline
\end{tabular}

The dependent variable in the regressions is the free cash flows, FCF, estimated following Richardson (2006). TPPS is the pay for performance sensitivity from stock options and restricted stock. DOVERTPS is the interaction variable between the dummy variable of positive overinvestment and TPPS. SPOVRED is the sensitivity of volatility orthogonal to TPPS. VP is a measure of growth opportunity and it is the ratio of the value of assets in place to current market price, LEV is the leverage ratio, CASH is the sum of the cash balance and short term investments deflated by total assets, AGE is the log of the number of years the firm has been listed in CRSP database, Lag(STR) is the lagged stock return, SIZE is the firm size, which is the log of total asset, and NEWINV is the total investment net of the investment of maintaining the assets in place. Because we merge the original sample with data in the ExecuComp database, the final sample in this test covers 4,849 observations. We report Newer-West t-statistics in parentheses. "*** , and "indicate significance levels of $1 \%, 5 \%$, and $10 \%$ respectively.

firm's financial flexibility, as measured by those free cash flows. $^{21}$

In Table 5, the overinvestment problem has significant effects on the relationship between incentive effects and free cash flows. Considering only the payfor-performance sensitivity in regression II, we find that the incentive effects are stronger in the firms with overinvestment. $^{22}$ After taking into account the sensitivity of volatility in regression IV, however, the significance of interaction terms between the overinvestment dummy and TPPS disappears. This implies that the effect of the sensitivity of volatility dominates that of the pay-for-performance sensitivity in

\footnotetext{
${ }^{21}$ To tighten the financial flexibility, managers can use many approaches other than investment, such as dividend payouts or share repurchasing.

${ }^{22}$ The overinvestment dummy is equal to one when firms have positive overinvestment and zero otherwise.
}

cases with overinvestment. Therefore, the impact of overinvestment on free cash flows diminishes after we consider both sensitivities.

In contrast to the negative impact of incentives on free cash flows, there is a significant positive impact of incentives on the problem of overinvestment. From Table 6, we find that overinvestment increases with both sensitivities. This result supports our previous explanation of the effect of incentives. One possible approach for managers is to alleviate the problem of free cash flows by investing more. This could cause managers to invest above their optimal level, which is the problem of overinvestment. In regression I, III, and IV, all positive impacts of sensitivities are significant at the $1 \%$ level. In addition, the level of free cash flows, interacting with the pay-for-performance sensitivity, has a significant negative effect on overinvestment. When firms have more free cash flows, the effect of 
Table 6: The Impact of Sensitivity of Stock-Based Compensation on Overinvestment

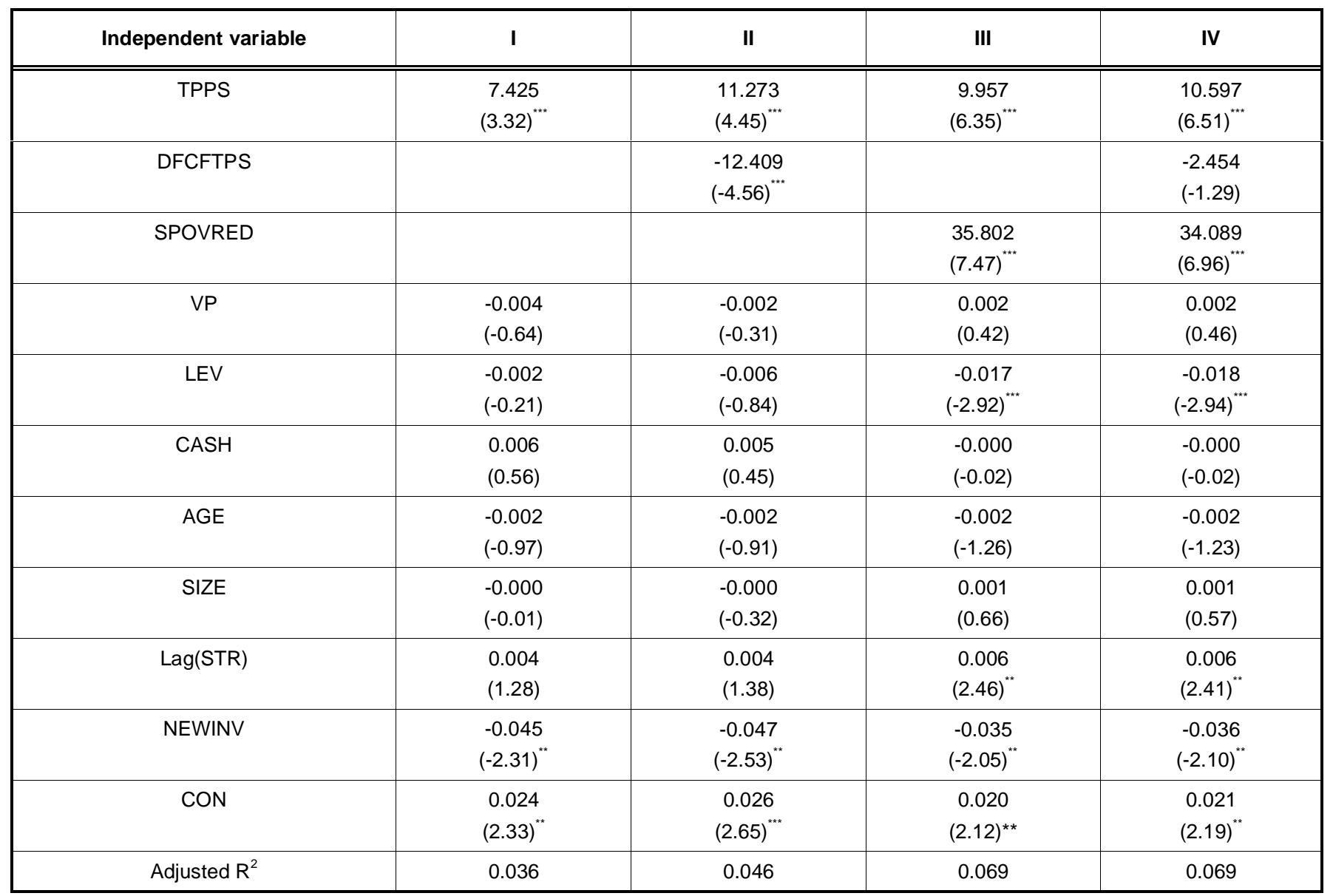

The dependent variable in the regressions is the measure of overinvestment, OVERINV, estimated following Richardson (2006). TPPS is the pay for performance sensitivity from stock options and restricted stock. DFCFTPS is the interaction variable between the dummy variable of positive free cash flow and TPPS. SPOVRED is the sensitivity of volatility orthogonal to TPPS. VP is a measure of growth opportunity and it is the ratio of the value of assets in place to current market price, LEV is the leverage ratio, CASH is the sum of the cash balance and short term investments deflated by total assets, AGE is the log of the number of years the firm has been listed in CRSP database, Lag(STR) is the lagged stock return, SIZE is the firm size, which is the log of total asset, and NEWINV is the total investment net of the investment of maintaining the assets in place. Because we merge the original sample with data in the ExecuComp database, the final sample in this test covers 4,849 observations. We report Newer-West t-statistics in parentheses. ${ }^{* * *}, "$, and " indicate significance levels of $1 \%, 5 \%$, and $10 \%$ respectively.

incentives on overinvestment becomes weaker. Adding the sensitivity of volatility in the regression, the significance of the interaction term disappears. The impact of the sensitivity dominates that of positive free cash flows interacting with the incentive. The analysis in Table $\mathbf{5}$ shows that the sensitivity of volatility plays a more important role than the interaction terms in explaining both agency problems.

\subsection{The Interaction between Incentives and Agency Problems}

The relations between the implied cost of capital, the agency problems, and incentive effects are shown in the previous analysis. To look at the impact of the agency problems on the implied cost of capital in more detail, we need to consider the interactions between the agency problems and the incentives from stockbased compensation. Testing for these interactions can help us to understand how these three topics are related to each other. To test the interaction variables between the agency problems and the incentives, we adopt a modified incentive measure that is the cumulated distribution function, CDF, of the incentives. We then use the product terms between the agency problems and the CDF of different sensitivities as a proxy for the interaction effect. ${ }^{23}$ Based on our previous findings, we create four interaction variables, PPSFCF, PPSOVER, PPVFCF, and PPVOVER, to take into account the effect of interactions between the agency problems and incentive effects. We summarize our results in Table 7.

\footnotetext{
${ }^{23}$ Because we need to construct the interaction term between the agency problems and the incentives, we use the original overinvestment measure rather than the dummy variable of overinvestment used in Table 3.
} 
Table 7: The Impact of Pay for Performance Sensitivity on the Implied Cost of Capital

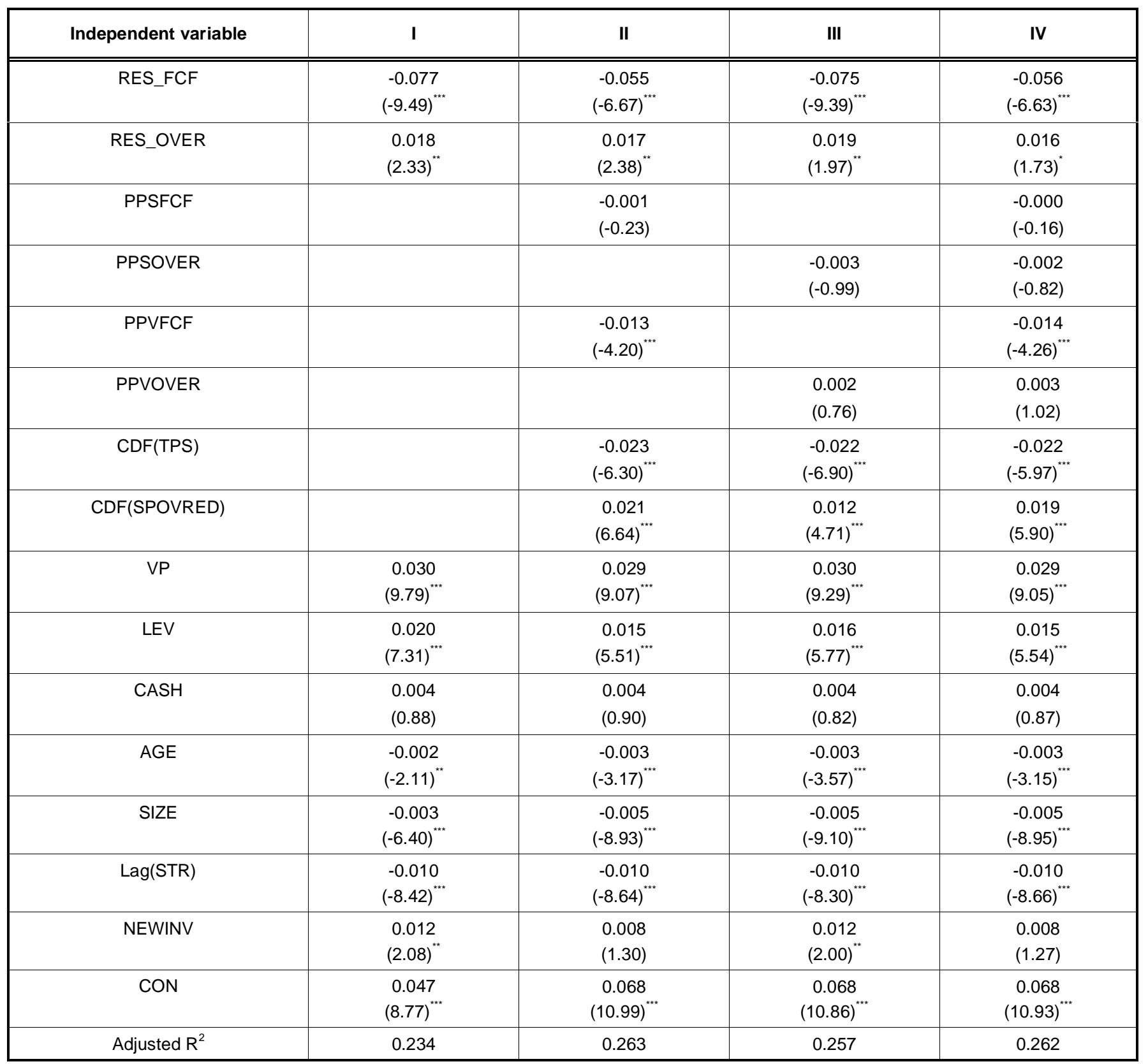

The dependent variable in the regressions is the implied cost of capital, ICC, estimated from the Ohlson-Juettner model. TPPS is the pay for performance sensitivity from stock options and restricted stock. RES FCF and RES OVER are the measures of free cash flows and overinvestment orthogonal to TPPS respectively. PPSFCF is the interaction variable between CDF(TPS) and the dummy variable of positive free cash flows. PPSOVER is the interaction variable between CDF(TPPS) and the dummy variable of positive overinvestment. PPVOVER is the interaction variable between the sensitivity to volatility and the dummy variable of positive overinvestment. All sensitivities are deflated by total assets. CDF are cumulated distribution function of each incentive measure. All control variables are the same as previous analysis. Because we merge the original sample with data in the ExecuComp database, the final sample in this test covers 4,849 observations. We report Newer-West t-statistics in parentheses. " ," , and " indicate significance levels of $1 \%, 5 \%$, and $10 \%$ respectively.

First, to verify both agency problems in the subsample merged with the ExecuComp database, we only run the regression of the implied cost of capital on two measures of the agency problems in regression . $^{24}$

\footnotetext{
${ }^{24}$ In the regressions of Table 7 , we use only the portion of free cash flows and overinvestment orthogonal to both incentive measures. In regression I, the significance of free cash flows and overinvestment still hold when we use the original measures of both problems.
}

The results show that both agency problems still affect the implied cost of capital significantly. Our previous analysis in Table $\mathbf{3}$ shows that free cash flows have a negative impact on financing costs. Overinvestment has a positive impact.

Second, in regressions II and III, the effects of incentive measures are consistent with the results in Table 4. The pay-for-performance sensitivity reduces 
the implied cost of capital but the sensitivity to volatility increases the financing cost. Based on the results of regressions I, II, and III, we conclude that the influence of both agency problems is still significant, even after taking the incentives into account. Finally, we add all of the interaction terms together in regression IV, and find that the original significance still holds. Among these interaction terms, only the interaction between the sensitivity of volatility and the dummy of free cash flows has a significant negative impact on the implied cost of capital. This implies that financial flexibility can reduce the effect of overinvestment due to the sensitivity to volatility.

\subsection{Robustness Check: Endogeneity Problems}

The estimations of free cash flows and overinvestment are based on the firm-specific variables and these variables are likely to correlate with executive compensation. In contrast, the executive compensation may also be affected by these variables. This is a potential endogeneity problem and we check the consistence of the previous empirical results by

Table 8: Robustness Check with Lagged Independent Variables

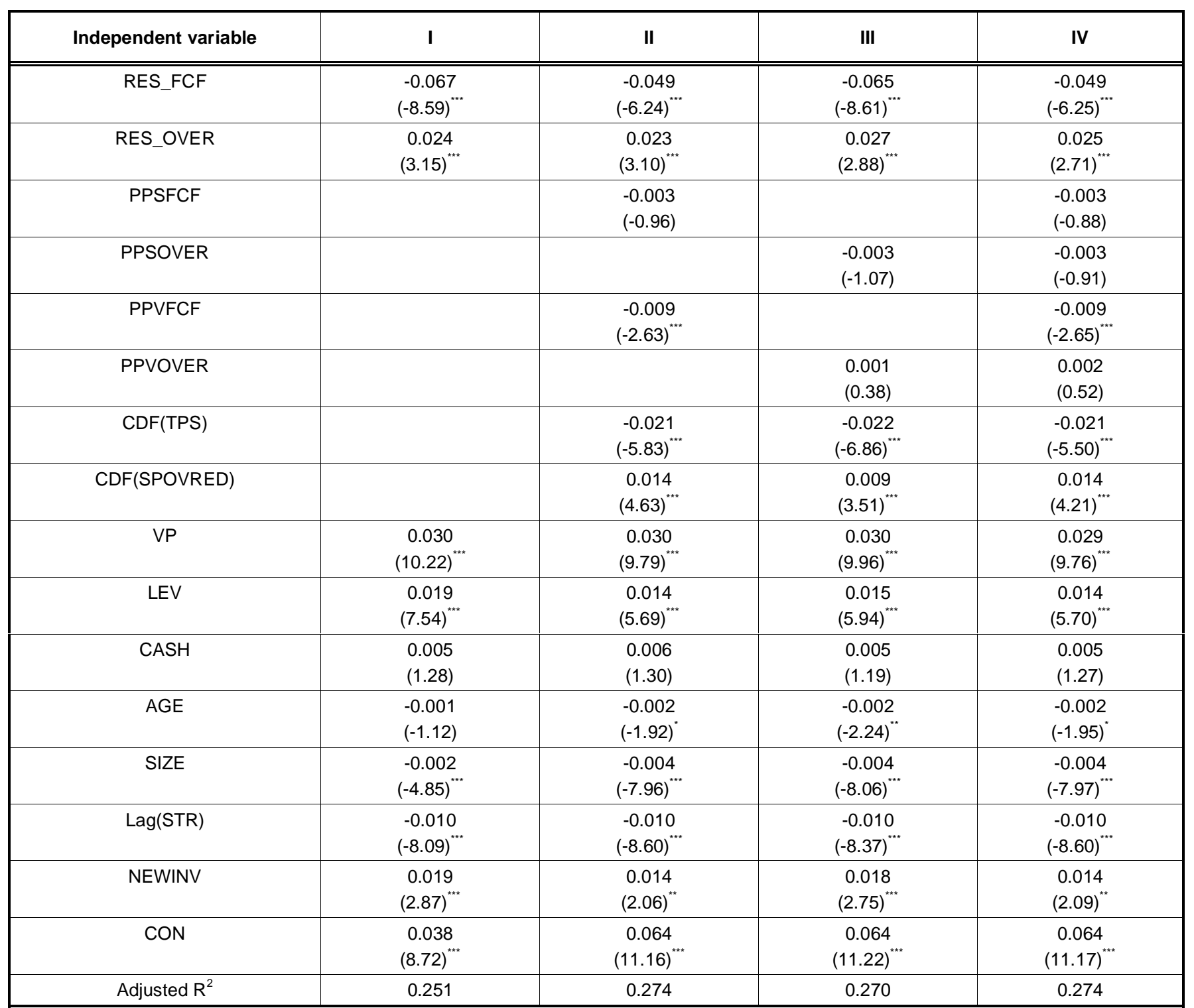

The dependent variable in the regressions is the implied cost of capital, ICC, estimated from the Ohlson-Juettner model. For all independent variables, we take the lagged value to alleviate the endogeneity problem. TPPS is the pay for performance sensitivity from stock options and restricted stock. RES_FCF and RES_OVER are the measures of free cash flows and overinvestment orthogonal to TPPS respectively. PPSFCF is the interaction variable between CDF(TPS) and the dummy variable of positive free cash flows. PPSOVER is the interaction variable between CDF(TPPS) and the dummy variable of positive overinvestment. PPVOVER is the interaction variable between the sensitivity to volatility and the dummy variable of positive overinvestment. All sensitivities are deflated by total assets. CDF are cumulated distribution function of each incentive measure. All control variables are the same as previous analysis. Because we merge the original sample with data in the ExecuComp database, the final sample in this test covers 4,849 observations. We report Newer-West t-statistics in parentheses. ", ", and " indicate significance levels of $1 \%, 5 \%$, and $10 \%$ respectively. 
using the lagged independent variables to conduct the previous tests in Table 7. The empirical results are in Table 8.

Comparing with the results in Table 7, we find that the results in Table 8 are qualitatively the same with those in Table 7 regarding the sign and the significance of lagged independent variables. The impact of both agency problems on the implied cost of capital has the same sign and similar significance. In addition, the payfor-performance sensitivity still reduces the implied cost of capital but the sensitivity to volatility increases the financing cost. Based on the results of regressions I, II, and III, we find the similar results after taking the endogeneity problem into account.

\section{CONCLUSION}

Agency problems have been discussed and analyzed for several decades, from Jensen and Meckling (1976), to now. In recent studies, Kalcheva and Lins (2007) claim that there is little evidence to show a link between poor corporate governance, high cash holdings, and lower values for firms. We try to fill in the gap and provide empirical evidence to show a relation between agency problems and lower firm values. We do not, however, test the value of a firm directly. Instead, we test the relation between agency problems and the implied cost of capital, because one major reason for the lower firm value is the high cost of capital. Based on the Ohlson-Juettner model, we perform empirical tests among the implied cost of capital, the agency problems, and incentives from stock-based compensation.

Testing the relationship between the implied cost of capital and free cash flows, we find that, on the one hand, investors take financial flexibility into account in the expectation of future returns. On the other hand, this impact reflects on the implied cost of capital, from the standpoint of the firm. Therefore, free cash flows, a proxy of financial flexibility, have a negative impact on future financial costs. In the similar test for overinvestment, we find a positive impact of overinvestment on the implied cost of capital, which suggests that overinvestment increases the risk level of a firm. As to the interaction between free cash flows and overinvestment, only the free cash flows in firms with positive overinvestment have a significant positive influence on the implied cost of capital. This result implies that free cash flows are more likely to be an agency problem when firms have positive overinvestment.

In the literature of executive compensation, many researchers implicitly assume that stock-based compensation provides incentives for managers to maximize shareholder wealth while alleviating the conflict of interest between managers and shareholders. We show that the incentives from the pay-for-performance sensitivity and the sensitivity to volatility have different impacts on the implied cost of capital. On the one hand, the pay-for-performance sensitivity induces managers to alleviate agency problems and, therefore, decreases future financing costs. On the other hand, the sensitivity of volatility makes managers invest more, and on riskier projects. Hence, these investment decisions could increase the cost of capital when investors are cognizant of these decisions.

The test of the relation between the agency problems and incentives supports our previous explanation. Because the increase in investment level requires more financial capital, the incentive effects have a significant negative impact on free cash flows but a positive impact on overinvestment. The negative effect on free cash flows is especially significant in firms with positive overinvestment. By contrast, the positive effect on overinvestment is less significant in firms with positive free cash flows. Therefore, the incentives have the expected results of reducing free cash flows but encourage investing more in riskier projects.

Finally, we find that both agency problems and incentive effects still significantly affect the implied cost of capital simultaneously. The financial flexibility measured by free cash flow and the pay-forperformance sensitivity has a negative impact, but the overinvestment and the sensitivity of volatility have positive impacts on the implied cost of capital. All these results are robust to the consideration of endogenity problems. These results suggest that both agency problems and incentive effects play important roles in explaining future financing costs. In addition, the current compensation mechanism could not alleviate both agency problems completely. Therefore, firms should focus on the overinvestment problem and also the sensitivity to volatility in compensation contracts. Free cash flows and pay-for-performance sensitivity could increase the value of a firm by reducing the cost of capital. Further research can extend out farther, based on these results.

\section{ACKNOWLEDGEMENT}

The author thanks the National Science Council for their financial support of this project, NSC96-2416- $\mathrm{H}$ 005-026. 


\section{APPENDIX I: THE COMPUTATION OF THE MARKET VALUE OF ASSET IN PLACE}

The computation in the Appendix follows Richardson (2006). First, the author decomposes the firm value into the value of asset in place and that of growth opportunity. Based on the residual income framework, we can find the asset in place, $V_{\text {AIP }}$, as follows,

$$
\begin{aligned}
& V_{A I P}=(1-\alpha r) B V+\alpha(1-r) X-\alpha r d \\
& \alpha=\frac{\omega}{1+r-\omega}
\end{aligned}
$$

where BV is book value of common equity,

$\mathrm{X}$ is earnings,

$r$ is discount rate,

d is dividend yield,

$\omega$ is a fixed persistence parameter and $0<\omega<1$.

Following Dechow et al. (1999), we set the discount rate equal to $12 \%$ and the persistence parameter equal to 0.62 . From the Compustat database, $\mathrm{BV}$ is the data item $60, d$ is the data item 21 , and $X$ is the data item 178.

\section{REFERENCES}

Aggarwal, R. K., and A. A. Samwick, 2006. Empire-builders and shirkers: Investment, firm performance, and managerial incentives. Journal of Corporate Finance 12, 489-515. http://dx.doi.org/10.1016/j.jcorpfin.2006.01.001

Albuquerque, R., and N. Wang, 2008. Agency conflicts, investment, and asset pricing. Journal of Finance 63, 1-40. http://dx.doi.org/10.1111/j.1540-6261.2008.01309.x

Ali, A., L.-S. Hwang and M. A. Trombley, 2003. Residual-incomebased valuation predicts future stock returns: Evidence on mispricing vs. risk explanations. The Accounting Review 78, 377-396. http://dx.doi.org/10.2308/accr.2003.78.2.377

Almeida, H., M. Campello, and M. S. Weisbach, 2004. The cash flow sensitivity of cash. The Journal of Finance 59, 1777-1804. http://dx.doi.org/10.1111/j.1540-6261.2004.00679.x

Baker, G. P., and B. J. Hall, 2004. CEO incentives and firm size. Journal of Labor Economics 22, 767-798. http://dx.doi.org/10.1086/423154

Barron, O. E., D. Byard, C. Kile and E. J. Riedl, 2002. Hightechnology intangibles and analysts' forecasts. Journal of Accounting Research 40, 289-312. http://dx.doi.org/10.1111/1475-679X.00048

Bizjak, J. M., J. A. Brickley, and J. L. Coles, 1993. Stock-based incentive compensation and investment behavior. Journal of Accounting and Economics 16, 349-372. http://dx.doi.org/10.1016/0165-4101(93)90017-A

Botosan, C. A., and M. A. Plumlee, 2005. Assessing alternative proxies for the expected risk premium. Accounting Review 80, 21-53. http://dx.doi.org/10.2308/accr.2005.80.1.21
Broussard, J. P., S. A. Buchenroth, and E. A. Pilotte, 2004. CEO incentives, cash flow, and investment. Financial Management 33, 51-70.

Byun, H.-Y., S.-K. Kwak, and L.-S. Hwang, 2008. The implied cost of equity capital and corporate governance practices. AsiaPacific Journal of Financial Studies 37, 139-184.

Cai, J., and A. M. Vijh, 2007. Incentive effects of stock and option holdings of target and acquirer CEOs. The Journal of Finance 62, 1891-1933. http://dx.doi.org/10.1111/j.1540-6261.2007.01260.x

Chen, K. C. W, Z. Chen, and K. C. J. Wei, 2011. Agency costs of free cash flow and the effect of shareholder rights on the implied cost of equity capital. Journal of Financial and Quantitative Analysis 46, 171-207. http://dx.doi.org/10.1017/S0022109010000591

Claus, J. and J. Thomas, 2001. Equity premia as low as three percent? Evidence from analysts' earnings forecasts for domestic and international stock markets. The Journal of Finance 56, 1629-1666. http://dx.doi.org/10.1111/0022-1082.00384

Core, J. E., and D. F. Larcker, 2002. Performance consequences of mandatory increases in executive stock ownership. Journal of Financial Economics 64, 317-340. http://dx.doi.org/10.1016/S0304-405X(02)00127-7

Core, J.E., Guay, W., 2002. Estimating the value of employee stock option portfolios and their sensitivities to price and volatility. Journal of Accounting Research 40, 613-630. http://dx.doi.org/10.1111/1475-679X.00064

Core, J. E., W. Guay, and D. F. Larcker, 2003. Executive equity compensation and incentives: A survey. Economic Policy Review 9, 27-50.

Dechow, P. M., A. P. Hutton, and R. G. Sloan, 1999. An empirical assessment of the residual income valuation model. Journal of Accounting and Economics 26, 1-34. http://dx.doi.org/10.1016/S0165-4101(98)00049-4

Easton, P. D., 2004. PE ratios, PEG ratios, and estimating the implied expected rate of return on equity capital. The Accounting Review 79, 73-95. http://dx.doi.org/10.2308/accr.2004.79.1.73

Easton, P. D., and S. J. Monahan, 2005. An evaluation of accounting-based measures of expected returns. Accounting Review 80, 501-538. http://dx.doi.org/10.2308/accr.2005.80.2.501

Garmaise, M. J., and J. Liu, 2005. Corruption, firm governance, and the cost of capital. Working Paper, UCLA.

Gebhardt, W. R., C. M. C. Lee, and B. Swaminathan, 2001. Toward an implied cost of capital. Journal of Accounting Research 39, 135-176. http://dx.doi.org/10.1111/1475-679X.00007

Gode, D., and P. Mohanram, 2003. Inferring the cost of capital using the Ohlson-Juettner model. Review of Accounting Studies 8 , 399-431.

http://dx.doi.org/10.1023/A:1027378728141

Guay, W., 1999. The sensitivity of CEO wealth to equity risk: An analysis of the magnitude and determinants. Journal of Financial Economics 53, 43-71. http://dx.doi.org/10.1016/S0304-405X(99)00016-1

Hail, L., and C. Leuz, 2006. International differences in the cost of equity capital: Do legal institutions and securities regulation matter? Journal of Accounting Research 44, 485-531. http://dx.doi.org/10.1111/j.1475-679X.2006.00209.x

Hail, L., and C. Leuz, 2009. Cost of capital effects and changes in growth expectations around U.S. cross-listings. Journal of Financial Economics 93, 428-454. http://dx.doi.org/10.1016/j.jfineco.2008.09.006

Hall, B. J., and K. J. Murphy, 2002. Stock options for undiversified executive. Journal of Accounting and Economics 33, 3-42. http://dx.doi.org/10.1016/S0165-4101(01)00050-7 
Hall, B. J., and J. Liebman, 1998. Are CEOs really paid like bureaucrats? Quarterly Journal of Economics 103, 653-691. http://dx.doi.org/10.1162/003355398555702

Hall, B. J. and T. A. Knox, 2004. Underwater options and the dynamics of executive pay-to-performance sensitivities. Journal of Accounting Research 42, 365-412. http://dx.doi.org/10.1111/j.1475-679X.2004.00142.x

Harford, J., 1999. Corporate cash reserves and acquisitions. The Journal of Finance 54, 1969-1997. http://dx.doi.org/10.1111/0022-1082.00179

Jensen, M. C., 1986. Agency cost of free cash flow, corporate finance and takeovers. The American Economic Review 76, 323-329.

Jensen, M. C., and K. J. Murphy, 1990. Performance pay and topmanagement incentives. Journal of Political Economy 98, 225-264. http://dx.doi.org/10.1086/261677

Jensen, M. C., and W. Meckling, 1976. Theory of the firm: Managerial behavior, agency costs and ownership structure. Journal of Financial Economics 3, 305-360. http://dx.doi.org/10.1016/0304-405X(76)90026-X

Kalcheva, I., and K. V. Lins, 2007. International evidence on cash holdings and expected managerial agency problems. The Review of Financial Studies 20, 1087-1112. http://dx.doi.org/10.1093/rfs/hhm023

Lang, L., and R. Litzenberger, 1989. Dividend announcements: cash flow signaling vs. free cash flow hypothesis? Journal of Financial Economics 24, 181-191. http://dx.doi.org/10.1016/0304-405X(89)90077-9

$\mathrm{Li}, \mathrm{X}$., 2015. Accounting conservatism and the cost of capital: An international analysis. Journal of Business Finance \& Accounting 42, 555-582. http://dx.doi.org/10.1111/jbfa.12121

McConnell, J. J., and H. Servaes, 1990. Additional evidence on equity ownership and corporate value. Journal of Financial Economics 27, 595-612. http://dx.doi.org/10.1016/0304-405X(90)90069-C

Mehran, H., 1995. Executive compensation structure, ownership, and firm performance. Journal of Financial Economics 38, 163184. http://dx.doi.org/10.1016/0304-405X(94)00809-F
Mikkelson, W. H., and M. M. Partch, 2003. Do persistent large cash reserves hinder performance? Journal of Financial Quantitative Analysis 38, 275-294. http://dx.doi.org/10.2307/4126751

Morck, R., A. Shleifer, and R. W. Vishny, 1988. Management ownership and market valuation - An empirical analysis. Journal of Financial Economics 20, 293-315. http://dx.doi.org/10.1016/0304-405X(88)90048-7

Myers, S. C., 1984. The capital structure puzzle. The Journal of Finance 56, 575-592. http://dx.doi.org/10.2307/2327916

Myers, S. C., and N. S. Majluf, 1984. Corporate financing and investment decisions when firms have information the investors do not have. Journal of Financial Economics 13, 187-221. http://dx.doi.org/10.1016/0304-405X(84)90023-0

Myers, S. C., and R. G. Rajan, 1998. The paradox of liquidity. Quarterly Journal of Economics 108, 733-771. http://dx.doi.org/10.1162/003355398555739

Officer, M. S., 2011. Overinvestment, corporate governance, and dividend initiations. Journal of Corporate Finance 17, 710724.

http://dx.doi.org/10.1016/j.jcorpfin.2010.06.004

Ohlson, J. A., B.E. Juettner-Nauroth, 2005. Expected EPS and EPS growth as determinants of value. Review of Accounting Studies 10, 349-365. http://dx.doi.org/10.1007/s11142-005-1535-3

Richardson, Scott, 2006. Over-investment of free cash flow. Review of Accounting Studies 11, 159-189. http://dx.doi.org/10.1007/s11142-006-9012-1

Stulz, R. M., 1995. Does the cost of capital differ across countries? An agency perspective. European Financial Management 2, $11-22$ http://dx.doi.org/10.1111/j.1468-036X.1996.tb00026.x

Stulz, R. M., 1999. Globalization, Corporate Finance and the Cost of Capital. Journal of Applied Corporate Finance 12, 8-25. http://dx.doi.org/10.1111/j.1745-6622.1999.tb00027.x

Yermack, D., 1995. Do corporations award CEO stock options effectively? Journal of Financial Economics 39, 237-269. http://dx.doi.org/10.1016/0304-405X(95)00829-4

Received on 02-03-2016

Accepted on 17-05-2016

Published on 03-06-2016

\section{DOI: http://dx.doi.org/10.6000/1929-7092.2016.05.18}

(C) 2016 Wu et al.; Licensee Lifescience Global.

This is an open access article licensed under the terms of the Creative Commons Attribution Non-Commercial License (http://creativecommons.org/licenses/by-nc/3.0/) which permits unrestricted, non-commercial use, distribution and reproduction in any medium, provided the work is properly cited. 